\title{
CHANGES IN ACID-BASE BALANCE OF UREMIC PATIENTS DURING HEMODIALYSIS ${ }^{1}$
}

\author{
BY JOHN M. WELLER, ${ }^{2}$ ROY C. SWAN, ${ }^{3}$ AND JOHN P. MERRILL * \\ (From the Department of Medicine, Peter Bent Brigham Hospital and Harvard Medical School, \\ Boston, Mass.)
}

(Submitted for publication February 20, 1953; accepted April 24, 1953)

Patients who are acutely or chronically ill with the uremic syndrome are clinically improved following the procedure of external hemodialysis. The exact changes responsible for this improvement are not known. It has been shown that dialysis removes retained nitrogenous metabolites and returns disordered serum electrolyte concentrations toward normal (1). The purpose of this study is to describe more precisely the changes in the acid-base balance present in uremic patients and their modification during hemodialysis.

\section{MATERIALS AND METHODS}

Ten patients having renal insufficiency were studied. One of these (D. B.) had acute renal failure due to paroxysmal myoglobinemia. On the day prior to hemodialysis, which was carried out on the ninth day of anuria, he was given 10 gms. of sodium bicarbonate intravenously. The other nine patients had chronic renal insufficiency. One (H. M.) had chronic glomerulonephritis; one (M. K.) had nephrosclerosis, and the others had chronic pyelonephritis. Four patients had received sodium bicarbonate orally prior to dialysis. Two (M. L. and F. M.) had 3 gms. daily for one week; one (E. C.) had 2 gms. daily for five days, and one (B. L.) had 12.5 gms. daily for three days.

Hemodialysis was applied to all patients by means of a modified Kolff-type artificial kidney (2). The dialysate bath in all cases contained per liter of bath $140 \mathrm{mEq}$. sodium, $4 \mathrm{mEq}$. potassium, $2.5 \mathrm{mEq}$. calcium, and $1.0 \mathrm{mEq}$. magnesium. In eight cases the bath chloride was 120 $\mathrm{mEq}$. per $\mathrm{L}$. and the bicarbonate $27 \mathrm{mEq}$. per L., while in two cases (D. B. and D. G.) the chloride was $112 \mathrm{mEq}$.

1 This work was supported (in part) by the Medical Research and Development Board, Office of the Surgeon General, Department of the Army, Contract No. DA-49007-MD-497, and (in part) by grants from the National Heart Institute, U. S. Public Health Service, and the American Heart Association.

2 Instructor in Medicine, Harvard Medical School; Junior Associate in Medicine, Peter Bent Brigham Hospital.

8 Life Insurance Medical Research Fellow.

4 Established Investigator, American Heart Association, Associate in Medicine, Harvard Medical School and Peter Bent Brigham Hospital. per $\mathrm{L}$. and the bicarbonate $35 \mathrm{mEq}$. per $\mathrm{L}$. The bath was maintained at approximately $\mathrm{pH} 7.4$ by equilibration with a 5 or 10 per cent carbon dioxide gas phase. The duration of dialysis was six hours in each case except one (E. G.) in which it was four hours. The bath was completely changed every two hours. Arterial samples of plasma, serum, or whole blood collected anaerobically were analyzed for serum $\mathrm{pH}$ by the method of Hastings and Sendroy (3) ; total $\mathrm{CO}_{2}$ content, Van Slyke and Neill (4) ; blood urea nitrogen, Archibald (5) ; serum sodium and potassium with a Barclay flame photometer using lithium as an internal standard; serum chloride, Schales and Schales (6) ; serum phosphorus, Fiske and Subbarow (7) ; and serum calcium, Clark and Collip (8).

\section{RESULTS}

The determined values of the percentage of packed red cells, Hct., the serum $\mathrm{pH}, \mathrm{pH}_{\mathrm{s}}$ and the serum total $\mathrm{CO}_{2}$ content, $\left(\mathrm{CO}_{2}\right)_{3}$, are shown in Table $\mathrm{I}$. Also given in Table $\mathrm{I}$ are the determined values of the blood urea nitrogen and the serum electrolytes including the serum total inorganic phosphorus in those cases in which it was analyzed. These values are shown for both the onset of dialysis ( 0 hour) and the end of dialysis (6 hours).

Calculated values of the components which delineate the acid-base balance are shown in Table II. The buffer base of the whole blood, $\left(B_{B}{ }^{+}\right)_{b}$, and the arterial (or alveolar) carbon dioxide pressure, $\mathrm{PCO}_{2}$, have been derived from the nomogram of Singer and Hastings (9). Their definitions of terms are used in this presentation. The buffer base is the calculated concentration of base equivalent to the sum of the concentrations of the buffer anions. The principal buffer anions are protein (both the hemoglobin of the red cells and the plasma proteins) and bicarbonate. In addition to these anions, a portion of the phosphate is likewise effective as a buffer. The buffer base is also equal to the difference between the sum of the cations (total base) and the sum of the non-buffer anions (chloride and other "fixed acids"). The 
TABLE I

Determined values at the beginning and end of hemodialysis

\begin{tabular}{|c|c|c|c|c|c|c|c|c|c|c|c|c|c|c|c|c|}
\hline \multirow[b]{2}{*}{ Patient } & \multicolumn{2}{|c|}{$\underset{\%}{\text { Hct. }}$} & \multicolumn{2}{|c|}{$\underset{\text { units }}{\mathrm{pH}}$} & \multicolumn{2}{|c|}{$\begin{array}{l}\left(\mathrm{CO}_{2}\right)_{s} \\
m M / L\end{array}$} & \multicolumn{2}{|c|}{$\underset{m E q .}{\left(\mathrm{Na}^{+}\right)_{L} .}$} & \multicolumn{2}{|c|}{$\underset{m E q . / L}{\left(K^{+}\right)_{s}}$} & \multicolumn{2}{|c|}{$\underset{m E q . / L}{\left(\mathrm{Cl}^{-}\right)^{\prime}}$} & \multicolumn{2}{|c|}{$\underset{m M / L .}{\operatorname{Inorg} .} P_{\mathrm{B}}$} & \multicolumn{2}{|c|}{$\underset{m g . / 100 \mathrm{ml} .}{\text { BUN }}$} \\
\hline & $\begin{array}{c}0 \\
\text { hr. }\end{array}$ & $\begin{array}{c}6 \\
\text { hrs. }\end{array}$ & $\begin{array}{c}0 \\
\text { hr. }\end{array}$ & $\begin{array}{c}6 \\
\text { hrs. }\end{array}$ & $\begin{array}{c}0 \\
\mathrm{hr} .\end{array}$ & $\begin{array}{c}6 \\
\text { hrs. }\end{array}$ & $\begin{array}{c}0 \\
\text { hr. }\end{array}$ & $\begin{array}{c}6 \\
\text { hrs. }\end{array}$ & $\begin{array}{c}\text { o } \\
\text { hr. }\end{array}$ & $\begin{array}{c}6 \\
\text { hrs. }\end{array}$ & $\begin{array}{c}0 \\
\text { hr. }\end{array}$ & $\begin{array}{c}6 \\
\text { hrs. }\end{array}$ & $\begin{array}{c}0 \\
\text { hr. }\end{array}$ & $\begin{array}{c}6 \\
\text { hrs. }\end{array}$ & $\begin{array}{c}0 \\
\mathrm{hr} .\end{array}$ & $\begin{array}{c}6 \\
\text { hrs. }\end{array}$ \\
\hline $\begin{array}{l}\text { B. L. } \\
\text { E. G.* } \\
\text { M. L. } \\
\text { F. M. } \\
\text { E. C. } \\
\text { M. K. } \\
\text { D. B. } \\
\text { D. G. } \\
\text { C. M. } \\
\text { H. M. }\end{array}$ & $\begin{array}{l}24.6 \\
37 \\
28 \\
30.2 \\
29 \\
19 \\
40 \\
27 \\
16 \\
18\end{array}$ & $\begin{array}{l}22 \\
33 \\
28 \\
27.3 \\
23 \\
19 \\
37 \\
25 \\
17 \\
27\end{array}$ & $\begin{array}{l}7.32 \\
7.32 \\
7.22 \\
7.22 \\
7.13 \\
7.32 \\
7.18 \\
7.37 \\
6.90 \\
6.97\end{array}$ & $\begin{array}{l}7.48 \\
7.38 \\
7.34 \\
7.37 \\
7.42 \\
7.53 \\
7.32 \\
7.70 \\
7.42 \\
7.26\end{array}$ & \begin{tabular}{r|}
15.8 \\
12.8 \\
23.4 \\
17.6 \\
12.9 \\
12.8 \\
16.5 \\
9.4 \\
9.9 \\
4.5
\end{tabular} & \begin{tabular}{r|}
20.8 \\
19.4 \\
25.2 \\
24.0 \\
21.4 \\
23.3 \\
18.5 \\
22.9 \\
20.3 \\
8.9
\end{tabular} & $\begin{array}{l}127 \\
124 \\
152 \\
135 \\
129 \\
119 \\
129 \\
123 \\
133 \\
133\end{array}$ & $\begin{array}{l}144 \\
130 \\
164 \\
135 \\
140 \\
135 \\
145 \\
140 \\
143 \\
141\end{array}$ & $\begin{array}{l}3.9 \\
6.7 \\
5.3 \\
3.9 \\
4.8 \\
7.3 \\
5.6 \\
5.4 \\
5.0 \\
7.2\end{array}$ & $\begin{array}{l}4.4 \\
5.3 \\
4.9 \\
4.4 \\
4.0 \\
5.4 \\
3.9 \\
3.9 \\
4.1 \\
5.5\end{array}$ & $\begin{array}{r}92 \\
92 \\
106 \\
96 \\
101 \\
77 \\
76 \\
87 \\
100 \\
85\end{array}$ & $\begin{array}{r}116 \\
99 \\
132 \\
120 \\
107 \\
94 \\
97 \\
107 \\
115 \\
-\end{array}$ & $\begin{array}{l}\frac{4.5}{2.7} \\
1.5 \\
\frac{5.2}{4.0} \\
6.9 \\
-\end{array}$ & $\begin{array}{l}\frac{1.6}{\overline{0}} \\
\frac{0}{1.8} \\
1.6 \\
\frac{-8}{-}\end{array}$ & $\begin{array}{l}215 \\
145 \\
205 \\
157 \\
140 \\
291 \\
207 \\
313 \\
355 \\
308\end{array}$ & $\begin{array}{r}76 \\
63 \\
80 \\
55 \\
27 \\
87 \\
108 \\
76 \\
116 \\
134\end{array}$ \\
\hline
\end{tabular}

* 4 hour values instead of 6 hour.

total base concentration and the non-buffer anion concentration are not directly altered by changes in respiration but are directly altered by changes in renal or gastro-intestinal excretion. These nonrespiratory changes are termed "metabolic" by Singer and Hastings. A primary metabolic disturbance producing either a decrease in total base concentration or an increase in non-buffer anion concentration results in a decrease in the buffer base concentration. This is termed a primary metabolic acidosis.

The carbon dioxide pressure of the arterial blood, $\mathrm{PCO}_{2}$, is in equilibrium with the alveolar carbon dioxide pressure. This may be rapidly altered by changes in pulmonary ventilation. A primary change in pulmonary ventilation which decreases the $\mathrm{PCO}_{2}$ is termed a primary respiratory alkalosis, while an increase in $\mathrm{PCO}_{2}$ is a respiratory acidosis.

A primary change in either the buffer base or the carbon dioxide pressure is usually accompanied by a secondary change in the other variable. These secondary or "compensatory" changes are in the direction which minimizes the deviation of the serum $\mathrm{pH}$. The selection of the primary change when mixed disturbances are present is based upon evaluation of the clinical situation.

Also given in Table II are the calculated concentrations of both the buffer and non-buffer serum anions. The serum bicarbonate ion concentration, $\left(\mathrm{HCO}_{3}{ }^{-}\right)_{8}$, and the serum protein ion concentration, (Prot $\left.{ }^{-}\right)_{s}$, have been derived from the nomogram of Singer and Hastings; the former directly, while the latter is the difference between the serum buffer base concentration, which is obtained directly from the nomogram, and the serum bicarbonate ion concentration. That fraction of the serum phosphate which is available as a buffer anion, $\left(\mathrm{HPO}_{4}^{-}\right)_{4}$, has been calculated from the determined total phosphate using the correspond-

TABLE II

Derived values at the beginning and end of hemodialysis

\begin{tabular}{|c|c|c|c|c|c|c|c|c|c|c|c|c|c|c|}
\hline \multirow[b]{2}{*}{ Patient } & \multicolumn{2}{|c|}{$\underset{m E q . / L}{\left(\mathrm{~B}_{\mathrm{B}^{+}}\right)_{\mathrm{b}}}$} & \multicolumn{2}{|c|}{$\begin{array}{r}\mathbf{P C O}_{\mathbf{g}} \\
\mathbf{m} . \mathrm{H}_{\mathbf{g}}\end{array}$} & \multicolumn{2}{|c|}{ 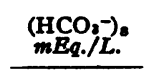 } & \multicolumn{2}{|c|}{$\begin{array}{c}\text { (Prot-) } \\
m E q . / L\end{array}$} & \multicolumn{2}{|c|}{ 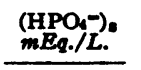 } & \multicolumn{2}{|c|}{$\underset{m E q . / L}{\left(B^{+}\right)}$} & \multicolumn{2}{|c|}{$\underset{m E q .}{\left(A^{-}\right)}$} \\
\hline & $\begin{array}{c}\mathbf{0} \\
\mathrm{hr} .\end{array}$ & $\begin{array}{c}6 \\
\text { hrs. }\end{array}$ & $\begin{array}{c}0 \\
\mathrm{hr} .\end{array}$ & $\begin{array}{c}6 \\
\text { hrs. }\end{array}$ & $\begin{array}{c}0 \\
\text { hr. }\end{array}$ & $\begin{array}{c}6 \\
\text { hrs. }\end{array}$ & $\begin{array}{c}0 \\
\text { hr. }\end{array}$ & $\begin{array}{c}6 \\
\text { hrs. }\end{array}$ & $\begin{array}{c}0 \\
\mathrm{hr} .\end{array}$ & $\begin{array}{c}6 \\
\text { hrs. }\end{array}$ & $\begin{array}{c}\mathbf{0} \\
\text { hr. }\end{array}$ & $\begin{array}{c}6 \\
\text { hr8. }\end{array}$ & $\begin{array}{c}0 \\
\text { hr. }\end{array}$ & $\begin{array}{c}6 \\
\mathrm{hr8}\end{array}$ \\
\hline $\begin{array}{l}\text { B. L. } \\
\text { E. G.* } \\
\text { M. L. } \\
\text { F. M. } \\
\text { E. C. } \\
\text { M. K. } \\
\text { D. B. } \\
\text { D. G. } \\
\text { C. M. } \\
\text { H. M. }\end{array}$ & $\begin{array}{l}35.2 \\
34.3 \\
40.0 \\
35.5 \\
29.8 \\
31.8 \\
34.8 \\
30.3 \\
22.1 \\
18.7\end{array}$ & $\begin{array}{l}42.0 \\
40.8 \\
44.0 \\
43.5 \\
41.8 \\
44.3 \\
39.2 \\
47.9 \\
39.7 \\
28.0\end{array}$ & $\begin{array}{l}29.4 \\
23.8 \\
53.8 \\
40.8 \\
36.0 \\
23.8 \\
41.5 \\
15.5 \\
45.1 \\
17.8\end{array}$ & $\begin{array}{l}27.1 \\
31.5 \\
45.1 \\
39.8 \\
32.3 \\
27.3 \\
34.6 \\
18.4 \\
30.8 \\
18.6\end{array}$ & \begin{tabular}{r|}
14.9 \\
12.2 \\
21.7 \\
16.3 \\
11.8 \\
12.1 \\
15.2 \\
8.9 \\
8.5 \\
4.0
\end{tabular} & $\begin{array}{l}20.0 \\
18.3 \\
23.8 \\
22.8 \\
20.4 \\
22.5 \\
17.4 \\
22.3 \\
19.3 \\
8.3\end{array}$ & $\begin{array}{l}16.8 \\
16.8 \\
16.1 \\
16.1 \\
15.7 \\
16.8 \\
16.0 \\
16.9 \\
13.5 \\
14.2\end{array}$ & $\begin{array}{l}18.2 \\
17.5 \\
17.0 \\
17.2 \\
17.9 \\
18.8 \\
16.9 \\
20.3 \\
18.0 \\
16.0\end{array}$ & $\begin{array}{r}7.3 \\
4.2 \\
2.3 \\
8.4 \\
6.0 \\
11.4 \\
-\end{array}$ & $\begin{array}{l}2.8 \\
- \\
1.3 \\
2.8 \\
2.6 \\
3.3 \\
-\end{array}$ & $\begin{array}{l}131 \\
131 \\
157 \\
139 \\
134 \\
126 \\
135 \\
128 \\
138 \\
140\end{array}$ & $\begin{array}{l}148 \\
135 \\
169 \\
139 \\
144 \\
140 \\
149 \\
144 \\
147 \\
147\end{array}$ & $\begin{array}{c}92 \dagger \\
102 \\
119 \\
104 \dagger \\
106 \\
89 \dagger \\
98 \dagger \\
91 \dagger \\
116 \\
122\end{array}$ & $\begin{array}{c}107 \dagger \\
99 \\
128 \\
98 \dagger \\
106 \\
96 \dagger \\
112 \dagger \\
98 \dagger \\
110 \\
123\end{array}$ \\
\hline
\end{tabular}

* 4 hour values instead of 6 hours.

$\dagger\left(\mathrm{HPO}_{4}\right)^{-}$, included in calculation. 


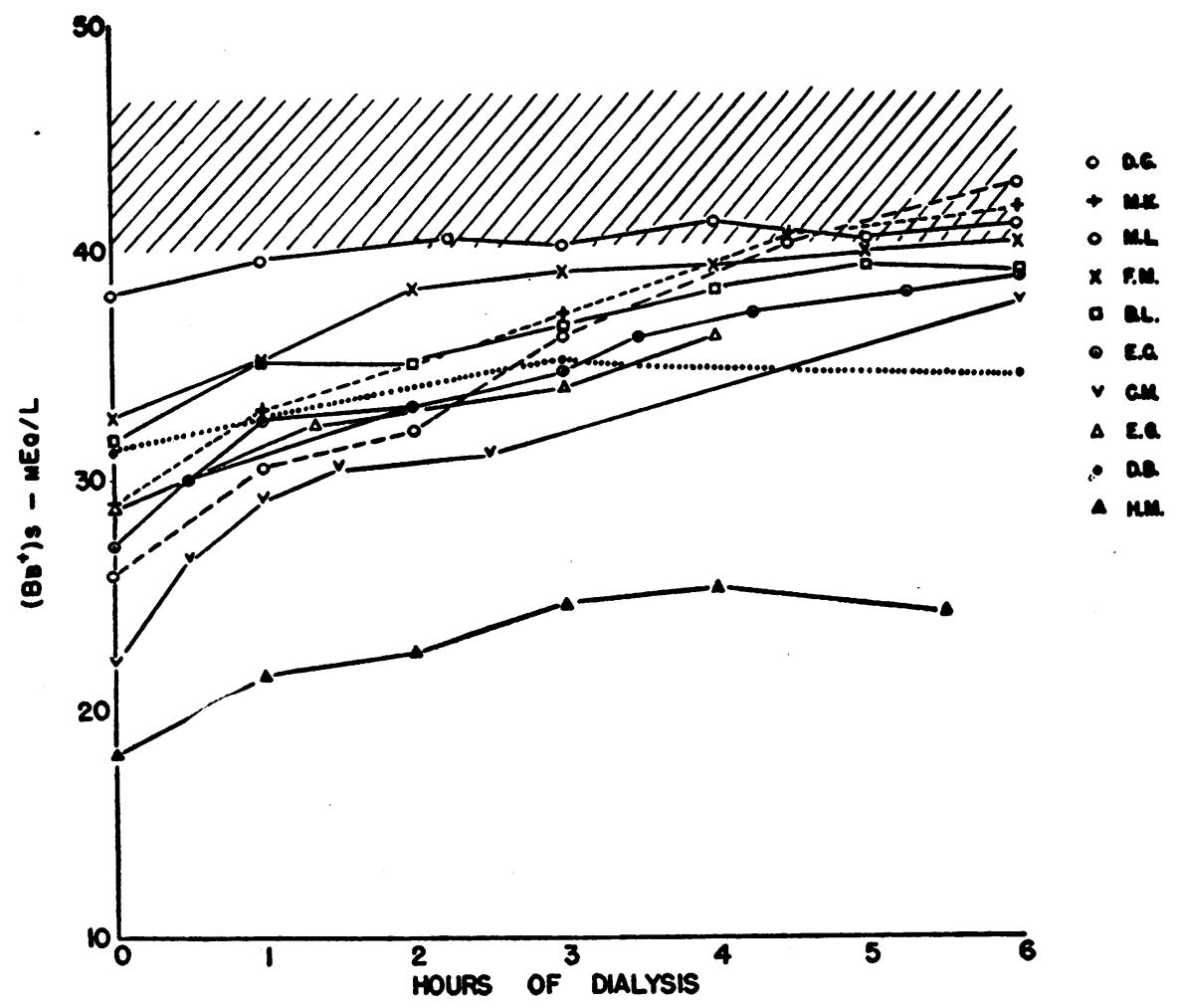

Fig. 1. The Changes with Time of the Serum Buffer Base of 10 Patients During Hemodialysis

The diagonally hatched area represents the normal range of the serum buffer base.

ing determined serum $\mathrm{pH}$. This fraction of the serum phosphate anion, the serum protein anion, and the serum bicarbonate anion together constitute the serum buffer anions.

The total serum base concentration is equal to the sum of the concentrations of the serum cations. Sodium is the principal serum cation. The calculated total serum base, $\left(\mathrm{B}^{+}\right)_{\mathrm{s}}$, given in Table II, is the sum of only the sodium and potassium. Calcium and magnesium are not included. The serum calcium was determined at both 0 and 6 hours in four cases with the following results: M. L., 3.2 to 5.0 ; M. K., 3.9 to 4.1 ; D. B., 2.5 to 3.0 , and D. G., 2.7 to $3.6 \mathrm{mEq}$. per L. The concentration of total serum non-buffer anions, or "fixed acids," $\left(\mathrm{A}^{-}\right)_{\mathrm{s}}$, is calculated by subtracting from the total serum base the sum of the serum buffer anions. Chloride constitutes the major portion of the nonbuffer serum anions. The phosphate fraction of the serum buffer anions has been onitted from this calculation in those cases in which it was not determined at both 0 and 6 hours.

\section{Acid-base balance prior to dialysis}

All patients except one (D. G.) were "acidotic" $\left(\mathrm{pH}_{\mathrm{s}}\right.$ lower than 7.35) prior to the commencement of hemodialysis. In two patients there was a marked lowering of the serum $\mathrm{pH}$ to below 7.0. All cases had a concentration of whole blood buffer base prior to dialysis which was below the lower limit of normal (45 mEq. per L.). Their acidosis was, therefore, of the metabolic type, and because all patients had renal insufficiency, this metabolic acidosis is considered to be the primary disturbance in the acid-base balance. The decreased whole blood buffer base concentration was due to a diminution in both the protein and the bicarbonate anion fractions. A decreased hemoglobin concentration present in all but two patients (E. G. and D. B.), as evidenced by the lowered hematocrits, accounted for the major portion of the decrease in the protein fraction. The absence of anemia in these two patients was correlated with the shorter duration of their uremia. The serum protein frac- 
tion of the buffer base was only slightly decreased. The lowered whole blood buffer base concentration prior to dialysis was also due to a decrease in the bicarbonate ion concentration as evidenced by the diminished concentration of serum bicarbonate. In all cases the serum bicarbonate was below the lower limit of normal ( $23 \mathrm{mEq}$. per L.). In contrast to the decrease in the concentration of the serum bicarbonate and protein anions there was an increase in the concentration of the buffer fraction of the serum phosphate anions due to renal retention of phosphate. This increase was not as great in magnitude as was the decrease in the principal buffer anions.

The decreased serum buffer base concentration may be the resultant of either a decrease in total serum base or an increase in the serum non-buffer anions. Eight patients had a concentration of total base below $140 \mathrm{mEq}$. per L. prior to dialysis. This decreased serum base was due to a diminished concentration of serum sodium. Only three patients prior to dialysis showed a significant increase (over $115 \mathrm{mEq}$. per L.) in the concentration of serum "fixed acids" (chloride and other non-buffer anions). Of the seven patients not having a "fixed acid" excess only one (E. C.) had a normal serum chloride concentration. The others had some degree of hypochloremia. The decrease in the serum chloride concentration of these patients offset the increase in the concentration of other "fixed acid" anions so that the total concentration of non-buffer anions was not increased. Of the three patients having a "fixed acid" excess, two (M. L. and C. M.) had normal serum chloride concentrations while the third (H. M.) had hypochloremia.

The primary metabolic acidosis present in these ten patients having renal insufficiency was, therefore, due to a decrease in buffer base concentration. This was associated with a total serum base deficit in eight patients while a "fixed acid" excess was present in only three.

Prior to dialysis, the arterial carbon dioxide pressure $\left(\mathrm{P}_{\mathrm{CO}_{2}}\right)$ was normal (between 35 and 48 $\mathrm{mm} . \mathrm{Hg}$ ) in four cases, slightly elevated in one and reduced in five. The lowered $\mathrm{CO}_{2}$ pressures in these five cases are considered to be secondary respiratory deviations (secondary respiratory

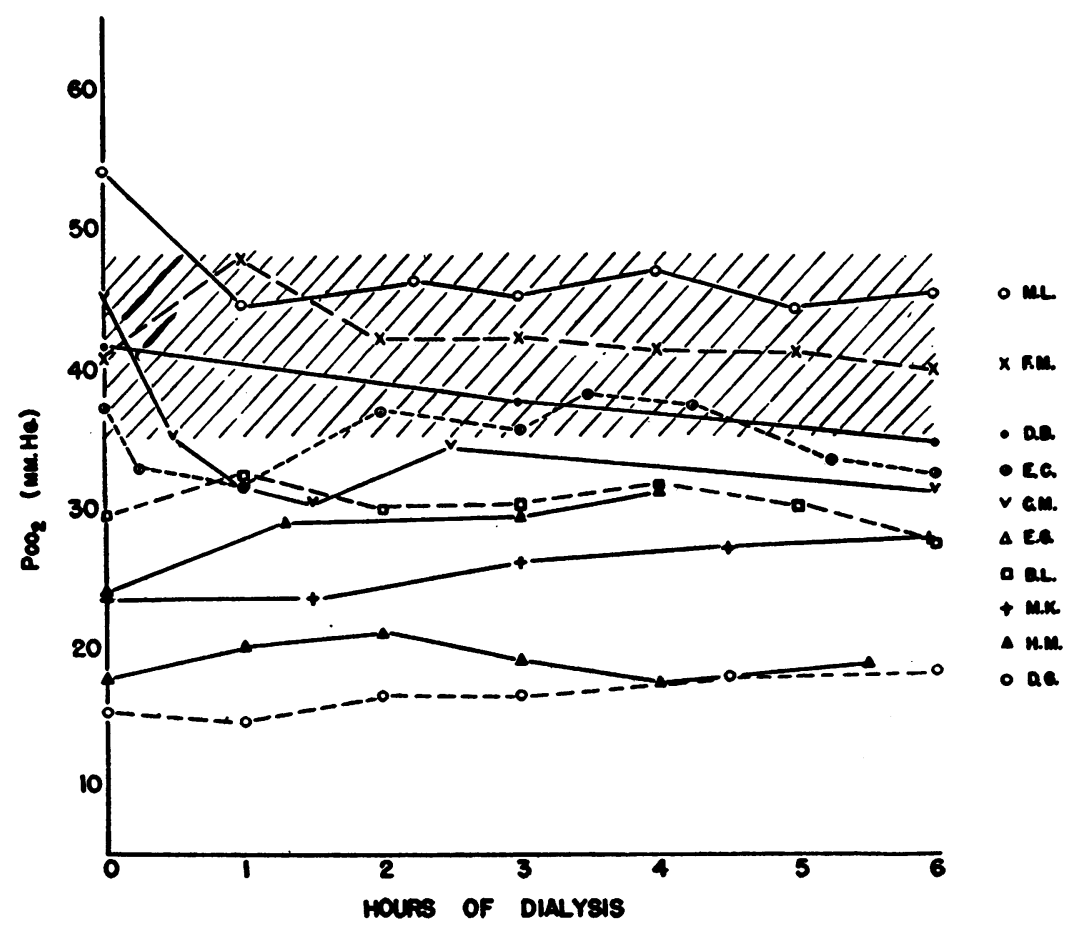

Fig. 2. The Changes with Time of the Arterial Carbon Dioxide Pressure of 10 Patients During Hemodialysis

The diagonally hatched area represents the normal range of the arterial carbon dioxide pressure. 


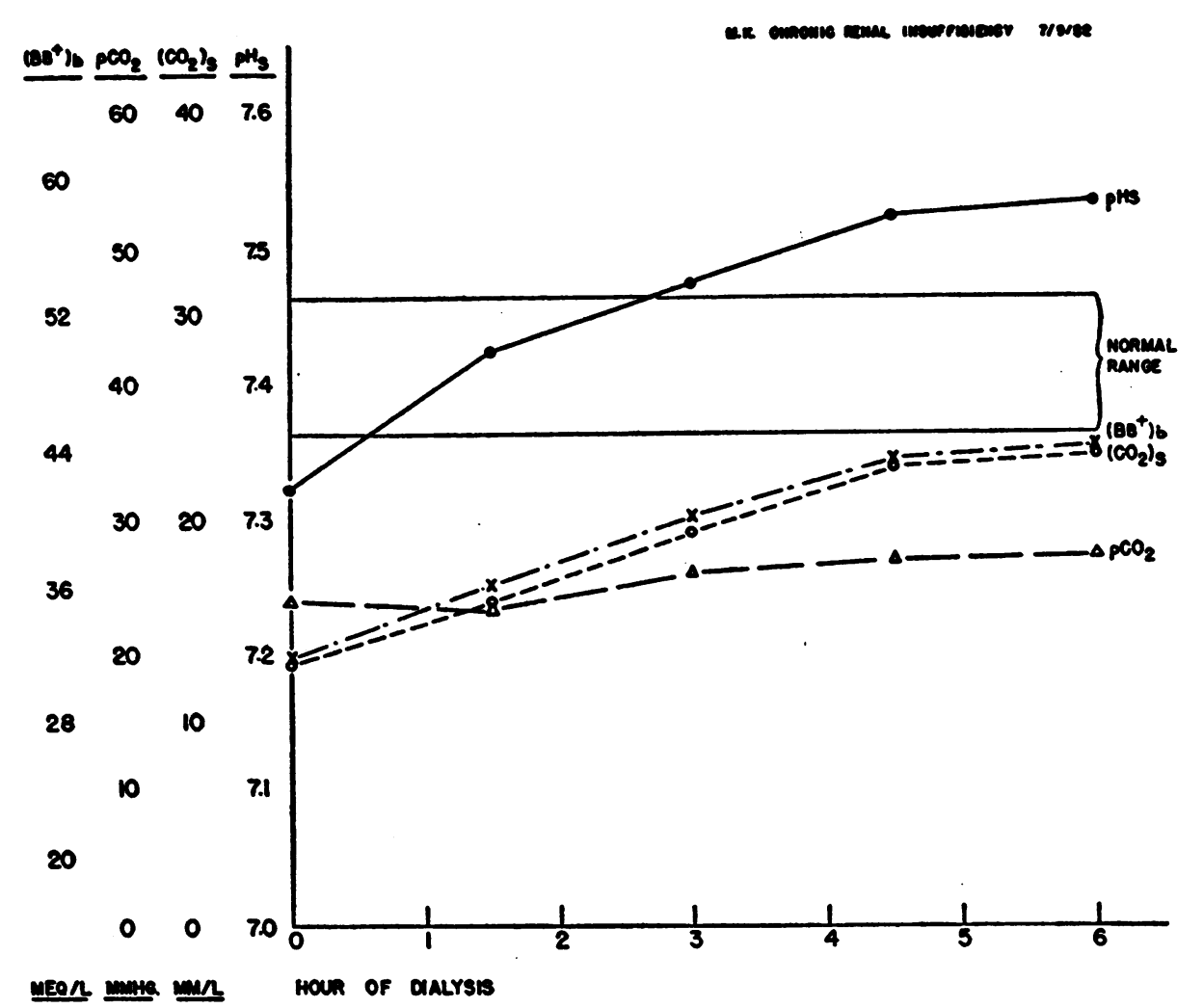

Fig. 3. Changes in the Whole Blood Buffer Base $\left(B_{B^{+}}\right)_{b}$; the Arterial Carbon Dioxide Pressure, $\left(\mathrm{P}_{\mathrm{CO}_{2}}\right)$; the Serum Total $\mathrm{CO}_{2}$ Content, $\left(\mathrm{CO}_{2}\right)_{\text {a, and }}$ the Serum pH, pH., in One Patient (M. K.) During Hemodialysis

alkalosis). These five patients, therefore, had a mixed disturbance of the acid-base balance, primary metabolic acidosis with secondary respiratory alkalosis.

\section{Changes in acid-base balance during dialysis}

It can be seen in Table II that in all instances dialysis resulted in an increase in the whole blood buffer base concentration. This change was not due to an increase in the concentration of the hemoglobin anion fraction of the whole blood buffer base as only one patient (H. M.) showed a significant increase in hematocrit. A small increase in the base equivalents of the protein anions present did occur in association with the increase in $\mathrm{pH}$. The major increase in the whole blood buffer base was accounted for by the increase in the bicarbonate ion fraction. In Figure 1 are shown the changes during the course of dialysis of the sum of the concentrations of the principal buffer anions of the serum (bicarbonate and protein). The serum phosphate fraction has not been included. As the serum protein anion fraction showed only a small change during dialysis, this increase in the serum buffer base was primarily due to an increase in the serum bicarbonate fraction. The rate of change of the serum buffer base is greater during the initial phase of dialysis.

The increase in the serum buffer base concentration' was associated with an increase in the serum total base concentration in all but one case. The increase in the serum total base was due primarily to an increase in the serum sodium. In addition there was an increase in the concentration of the chloride fraction of the "fixed acids" in all instances, but at the same time, this increase was in part offset by a decrease in the concentration of other non-buffer anions. Dialysis, therefore, resulted in alleviation of the metabolic acidosis by increasing the whole blood buffer base, primarily by increasing the bicarbonate anion concentration. Dialysis also moderated both the serum total base deficit and the hypochloremia and decreased the serum concentration of other "fixed acids." 
This prompt correction of the metabolic acidosis occurs without any consistent change in the respiratory component of the acid-base balance. The $\mathrm{P}_{\mathrm{CO}_{2}}$ showed little change during dialysis (Figure 2). The patients that had a secondary respiratory alkalosis (low $\mathrm{PCO}_{2}$ ) at the onset of dialysis had persistence of this low arterial $\mathrm{P}_{\mathrm{CO}_{2}}$ throughout the course of dialysis. As the primary metabolic acidosis was alleviated by dialysis, this persistence of the lowered $\mathrm{P}_{\mathrm{CO}_{2}}$ resulted in three cases (B. L., M. K., and D. G.) in actual alkalosis $\left(\mathrm{pH}_{\mathrm{s}}\right.$ above 7.46$)$ at the end of dialysis. Figure 3 shows the development of this alkalosis during dialysis in one of these patients (M. K.) and also shows the changes with time of the other determined and calculated values which describe the acid-base disturbance.

\section{DISCUSSION}

These ten patients with renal insufficiency were all seriously ill and were considered to be in the terminal phase of their disease at the time of dialysis. Indeed, all nine of the patients with chronic renal insufficiency subsequently succumbed. The one patient (D. B.) with acute renal insufficiency recovered. However, all of the patients except one (H. M.) showed a good clinical response to dialysis and survived for many weeks. The one patient who did not respond was moribund at the time of dialysis and died shortly after the termination of the procedure.

All of the patients dialyzed had a metabolic acidosis (decreased whole blood buffer base concentration). This was due to a decrease in both the protein (primarily hemoglobin) and bicarbonate fractions of the buffer base. Dialysis caused a slight increase in the protein fraction and a much larger increase in the bicarbonate fraction. Conservative treatment utilizing both whole blood or red cell transfusions and sodium bicarbonate or lactate will result in an increase in both fractions of the buffer base (10). Only one (H. M.) of the patients in this study received blood during dialysis. However, the use of the artificial kidney does not preclude the administration of blood either during the procedure or independently. Restoration of buffer base, therefore, occurs during both dialysis and conservative therapy.

All patients showed a decrease in total serum base concentration which was moderated by dialysis. Conservative therapy also alleviates total base deficit. "Fixed acid" excess was present in only three of the ten patients. However, of the seven patients having no increase in the total serum nonbuffer anion concentration, six had hypochloremia which offset the increase in the non-chloride "fixed acids." Hemodialysis results in correction of the hypochloremia and reduction of non-chloride "fixed acids." Conservative treatment on the other hand usually results in further hypochloremia and does not reduce significantly the level of other "fixed acids."

The development of respiratory alkalosis in three patients during correction of the metabolic acidosis by dialysis is similar to that resulting from conservative therapy, utilizing sodium lactate, as reported by Yeomans and Stueck (Case I) (10). The production of respiratory alkalosis by alkali therapy of metabolic acidosis is not confined to the treatment of renal acidosis but has been noted previously during the treatment of diabetic acidosis. This substitution of a primary respiratory alkalosis for a primary metabolic acidosis has been elaborated on by Singer and Hastings (9). Wallace has also discussed this lag in respiratory adjustment during base administration and has pointed out that there is independence of the acidbase balance of intra- and extracellular fluids and that rapid alkali therapy has a minimal effect on intracellular $\mathrm{pH}$ (11). The rapidity of change of the serum bicarbonate concentration during dialysis suggests that the extracellular fluid rather than total body water is equilibrating with the dialysate bath. This is in accord with the observation of Rosenbaum that intravenous bicarbonate appeared to be limited in its distribution to the extracellular fluid (12). Wallace and Hastings (13) also found that the bicarbonate concentrations in muscle cells is not changed by elevation of the serum bicarbonate if the $\mathrm{PCO}_{3}$ is unchanged. It would appear that during dialysis, although there is a prompt change in the extracellular bicarbonate concentration and $\mathrm{pH}$, there is little change in the intracellular bicarbonate and $\mathrm{pH}$, with the result that there is little change in the metabolism within the respiratory center and, therefore, no stimulus for alternation of the respiratory exchange and $\mathrm{P} \mathrm{CO}_{2}$. A secondary respiratory alkalosis which is present at the onset of dialysis can by this means persist and be the sole disturbance of the acid-base balance at the end of dialysis when the primary metabolic acidosis has been corrected. 
The rapidity of the onset of clinical improvement following dialysis varies according to the disease state present. The removal by dialysis of a toxic ion such as bromide results in clinical improvement within a few hours (14). The bromide ion is present primarily in the extracellular fluid and can be readily removed by dialysis. Patients having the uremic syndrome, however, do not show such a prompt clinical response. Those with acute renal insufficiency usually improve clinically within 24 hours, while those with chronic renal insufficiency may not improve for 48 or 72 hours. It would seem doubtful in these cases of chronic renal insufficiency that the efficacy of hemodialysis is directly due to the removal of a toxic metabolite which has accumulated primarily in the extracellular fluid or which is easily diffusible between the intracellular and extracellular fluids. Likewise, the delayed clinical improvement cannot be directly correlated with the correction of the lowered $\mathrm{pH}$, decreased buffer base, hypochloremia, or "fixed acid" excess. All of these change rapidly during dialysis. However, it is possible that a delay in the readjustment of the intracellular $\mathrm{pH}$ and cellular metabolism may explain the delay following dialysis before clinical improvement is shown by chronically ill, severely uremic patients.

\section{SUMMARY}

The changes in the acid-base balance during hemodialysis have been studied' in ten uremic patients. Nine of the patients were acidotic with a lowered serum $\mathrm{pH}$. All ten patients had a primary metabolic acidosis with a diminished whole blood buffer base concentration due to a decreased concentration of both the protein and bicarbonate anions. Eight patients had a diminished total serum base concentration, and three had "fixed acid" excess. Five patients had a secondary respiratory alkalosis.

Hemodialysis alleviated the acidosis; increased the buffer base concentration, primarily by increasing the bicarbonate fraction; increased the total serum base concentration, and removed nonchloride "fixed acids," but at the same time, corrected hypochloremia. The respiratory alkalosis, when present, persisted unchanged throughout dialysis.
The relationships between these changes in the acid-base balance and clinical improvement following hemodialysis have been discussed.

\section{ACKNOWLEDGMENT}

The authors wish to express their appreciation to Professor A. Baird Hastings for his helpful criticism of the manuscript.

\section{REFERENCES}

1. Merrill, J. P., Smith, S., III, Callahan, E. J., III, and Thorn, G. W., The use of an artificial kidney. II. Clinical experience. J. Clin. Invest., 1950, 29, 425.

2. Murphy, W. P., Jr., Swan, R. C., Jr., Walter, C. W., Weller, J. M., and Merrill, J. P., Use of an artificial kidney. III. Current procedures in clinical hemodialysis. J. Lab. \& Clin. Med., 1952, 40, 436.

3. Hastings, A. B., and Sendroy, J., Jr., Studies of acidosis. XX. The colorimetric determination of blood $\mathrm{pH}$ at body temperature without buffer standards. J. Biol. Chem., 1924, 61, 695.

4. Van Slyke, D. D., and Neill, J. M., The determination of gases in blood and other solutions by vacuum extraction and manometric measurement. I. J. Biol. Chem., 1924, 61, 523.

5. Archibald, R. M., Colorimetric determination of urea. J. Biol. Chem., 1945, 157, 507.

6. Schales, O., and Schales, S. S., A simple and accurate method for the determination of chloride in biological fluids. J. Biol. Chem., 1941, 140, 879.

7. Fiske, C. H., and Subbarow, Y., The colorimetric determination of phosphorus. J. Biol. Chem., 1925, 66, 375 .

8. Clark, E. P., and Collip, J. B., A study of the Tisdall method for the determination of blood serum calcium with a suggested modification. J. Biol. Chem., 1925, 63, 461.

9. Singer, R. B., and Hastings, A. B., An improved clinical method for the estimation of disturbances of the acid-base balance of human blood. Medicine, 1948, 27, 223.

10. Yeomans, A., and Stueck, G. H., Jr., Clinical-chemical studies of acid-base abnormalities. Changes in acid-base balance observed in renal and respiratory disease. Am. J. Med., 1952, 13, 183.

11. Wallace, W. M., Some aspects of the chemical composition, physiology and pathology of intracellular fluid. Pediatrics, 1952, 9, 141.

12. Rosenbaum, J. D., The influence of alterations in acidbase balance upon transfers of carbon dioxide and bicarbonate in man. J. Clin. Invest., 1942, 21, 735.

13. Wallace, W. M., and Hastings, A. B., The distribution of the bicarbonate ion in mammalian muscle. $\mathrm{J}$. Biol. Chem., 1942, 144, 637.

14. Merrill, J. P., and Weller, J. M., Treatment of bromism with the artificial kidney. Ann. Int. Med., $1952,37,186$. 